\title{
TINGKAT KEPUASAN PETANI TERHADAP KINERJA PENYULUH LAPANGAN (STUDI KASUS DI DESA SUKASARI KECAMATAN CILAKU KABUPATEN CIANJUR)
}

\author{
Oleh: \\ Asep Saepul Alam*) \\ Neta Oktavianti**)
}

\begin{abstract}
Abstrak
Kepuasan adalah perasaan senang atau kecewa seseorang yang muncul setelah membandingkan antara persepsi atau kesannya terhadap kinerja atau hasil suatu produk dan harapan - harapannya. Kinerja adalah hasil kerja secara kualitas dan kuantitas yang dicapai oleh seseorang pegawai dalam melaksanakan tugasnya sesuai dengan tanggung jawab yang diberikan kepadanya. Fungsi penyuluh pertanian merupakan untuk melakukan pengembangan kemampuan, pengetahuan, keterampilan serta sikap pelaku utama (petani) dan pelaku usaha melalui penyuluhan. Penelitian ini bertujuan untuk mengetahui atribut pelayanan penyuluh lapangan terhadap kelompok tani dan mengetahui tingkat kepuasan kelompok tani terhadap kinerja penyuluh lapangan. Penelitian ini dilaksanakan di Gapoktan Seroja Desa Sukasari Kecamatan Cilaku Kabupaten Cianjur, sejak bulan Juni sampai dengan bulan Juli 2019. Berdasarkan hasil penelitian ini menunjukan dari data penilaian tingkat kepentingan maupun tingkat kinerja, dengan nilai rata-rata tingkat kepentingan sebesar 1,86 dan tingkat kinerja dengan nilai rata-rata 1,80. Hal ini menunjukan tingkat kepuasan petani yang kurang merasa puas atas kinerja yang diberikan oleh penyuluh lapangan di Desa Sukasari Kecamatan Cilaku Kabupaten Cianjur dan Hasil pengolahan data yang telah diperoleh dari Costumer Satification Index (CSI) sebesar 38,31\%, nilai tersebut ada pada rentang antara $20 \%<$ CSI $\leq 40 \%$. Menunjukan petani merasa kurang puas atas atribut atau peran yang dilakukan oleh penyuluh lapangan.
\end{abstract}

Kata Kunci : Tingkat Kepuasan, Kinerja, dan Penyuluh Lapangan.

\begin{abstract}
Satisfaction is a feeling of pleasure or disappointment someone who appears after comparing between perception or impression of the performance or results of a product and expectations - expectations. Performance is the result of quality and quantity of work achieved by an employee in carrying out their duties in accordance with the responsibilities given to him. The function of agricultural extension is to develop the capabilities, knowledge, skills and attitudes of the main actors (farmers) and business actors through counseling. This study aims to determine the attributes of field extension services to farmer groups and determine the level of satisfaction of farmer groups to the performance of field extension workers. This research was conducted in Gapoktan Seroja, Sukasari Village, Cilaku District, Cianjur Regency, from June to July 2019. Based on the results of this study indicate the assessment of the level of importance and performance level, with an average value of 1.86 and the level of performance with an average value of 1.80. This shows the level of satisfaction of farmers who are less satisfied with the performance given by the field instructor in Sukasari Village, Cilaku District, Cianjur District and the results of data processing obtained from the Customer Satification Index (CSI) of 38.31\%, the value is in the range between $20 \%<C S I \leq 40 \%$. Shows farmers feel less satisfied with the attributes or roles carried out by the field instructor.
\end{abstract}

Keywords : Satisfaction Level, Performance, and Field Ekstension.

*) Dosen Fakultas Sains Terapan UNSUR

**) Alumni Fakultas Sains Terapan UNSUR 


\section{PENDAHULUAN}

Kegiatan penyuluhan pertanian merupakan kegiatan yang sangat dibutuhkan untuk mampu mencukupi kebutuhan petani dalam hal kegiatan pertanian. Hal ini karena $40 \%$ jumlah penduduk yang bekerja di sektor pertanian yaitu sekitar 38,973,033 orang dari total penduduk usia produktif dan sisanya $60 \%$ tersebar di luar sektor pertanian. Sektor pertanian sendiri dalam penerapannya terbagi dalam berbagai macam sub sektor. Oleh karena itu, BPS (2014) mengatakan bahwa kegiatan penyuluhan ini sangat penting dalam penerapan berbagai sub sektor pertanian bagi para petani dalam memajukan sektor pertanian tersebut.

Dalam program penyuluhan pertanian, Pemerintah merupakan salah satu bagain yang memiliki peranan penting untuk mensejahterakan rakyatnya sebagaimana yang telah tercantum di Peraturan Menteri Pertanian Nomor 273/KPTS/OT.160/4/2007, pada tanggal 13 april 2007 tentang Pedoman Pembinaan Kelembagaan Petani. Sejalan dengan adanya Undang-undang Nomor 19 Tahun 2013 tentang Pemberdayaan Petani dan Undang-undang No. 16 Tahun 2006 tentang Revitalisasi Pertanian, Perkebunan dan Kehutanan (RPPK) maka pemerintah mewujudkan revitalisasi pertanian yang luas, sehingga mampu mencerdaskan para petani, dapat merubah sistem pertanian untuk lebih maju dan mendapatkan keuntungan yang lebih banyak. Berdasarkan udang-undang tersebut, perlu diadakannya perangkat penyuluh pertanian yang tidak hanya profesional tetapi harus proaktif terhadap petani dan petani diatur serta ditata dalam wadah kelompok tani di tiap desa di tingkat Kecamatan sehingga memudahkan proses penyuluhan pertanian.

Menurut Mardikanto mengatakana bahwa penyuluhan pertanian merupakan sebagai salah satu pendidikan non formal yang meliputi proses belajar mengajar secara berlangsung dengan memberikan pengetahuan dan keterampilan dari penyuluh kepada petani ataupun keluarganya. Penyuluhan ini sebagai upaya untuk mencerdaskan kehidupan bangsa dan memajukan kesejahteraan umum sehingga pemerintah berkewajiban menyelenggarakan penyuluhan baik bagi di bidang pertanian, perikanan, dan kehutanan.

Penyuluhan pertanian bertujuan untuk mengubah perilaku utama dan pelaku usaha melalui peningkatan pengetahuan, keterampilan, sikap dan memotivasi agar semakin mandiri serta mandiri (Departemen pertanian, 2009). Selain daripada itu, adanya pembinaan kelompok tani pun diharapkan dapat memecahkan masalah usaha tani anggotanya secara efektif, membantu menggali potensi dan memudahkan dalam mengakses informasi baik pasar, teknologi, permodalan atupun sumbedaya lainnya.

Karena keberhasilan pembangunan pertanian bukan hanya ditentukan oleh kondisi sumberdaya petanian, tetapi juga ditentukan oleh peran penyuluh pertanian yang itu sendiri yang diharapkan mampu menyusun rencana kerja dan melaksanakan penyuluhan berbasis pertanian yang sesuai dengan kebutuhan masyarakatnya.

Pada saat ini penyuluh dalam melakukan tugasnya baru sebatas satu arah yaitu penyebaran informasi perubahan dari kepentingan institusinya ke petani dari para ilmuwan, yang ditransfer oleh pekerja komunikasi seperti agen penyuluhan dan diterapkan oleh praktisi pertanian. Model seperti ini biasa disebut model inovasi linier, seperti yang dijelaskan oleh Kline dan Rosenberg dalam Leewis (2009) model inivaasi linier yang menggambarkan garis lurus dan satu arah diantara ilmu dan praktik.

Salah satu permasalahan dalam meningkatkan produksi pertanian antara lain materi penyuluhan yang kurang sesuai dengan kondisi yang ada dan tingkat produktivitas pertanian yang rendah. Oleh karena itu, perlu adanya peranan penting 
untuk membantu permasalahan tersebut yaitu bagian dari tugas penyuluh untuk terus menerus berusaha mengetahui faktor - faktor yang dapat memberikan kepuasan kepada petani, karena dengan itu penyuluh dapat mengalokasikan sumberdaya secara tepat dan berhasil.

Tersediannya penyuluh di suatu desa tidak menjamin dapat memberikan hasil yang sama karena tergantung bagaimana penyuluh dapat memberikan kepuasan terhadap petani dengan kinerja yang dihasilkan. Kepuasan merupakan perasaan senang atau kecewa yang muncul setelah membandingkan antara pelayanan yang dipikirkan terhadap hasil yang diharapkan.

Untuk itu diperlukan suatu pengukuran tingkat kepuasan petani terhadap kinerja penyuluh pertanian demi mengetahui faktor - faktor yang dianggap penting dan diharapkan oleh petani, sehingga dengan meningkatkan kinerja faktor - faktor tersebut akan dapat memuaskan petani.

Dari uraian tersebut maka penulis tertarik untuk meneliti dengan judul “ Tingkat Kepuasan Petani Terhadap Penyuluh Lapangan di Desa Sukasari Kecamatan Cilaku Kabupaten Cianjur.

\section{METODE PENELITIAN}

Di Kelompok Tani di Desa Sukasari Kecamatan Cilaku Kabupaten Cianjur. Waktu pelaksanaan penelitian dilakukan selama dua bulan yaitu dari bulan Juni - Juli 2019.

Dalam penelitian ini yang menjadi variabel bebas (X) adalah Tangible, Reliability, Responsiveness, Assurance dan Emphathy. Sedangkan untuk variabel terikat (Y) adalah Kepuasan Konsumen. Dalam penelitian ini penulis mengoperasionalkan varibel penelitian seperti pada tabel 1. sebagai berikut :

Tabel 1. Operasionalisasi Variabel.

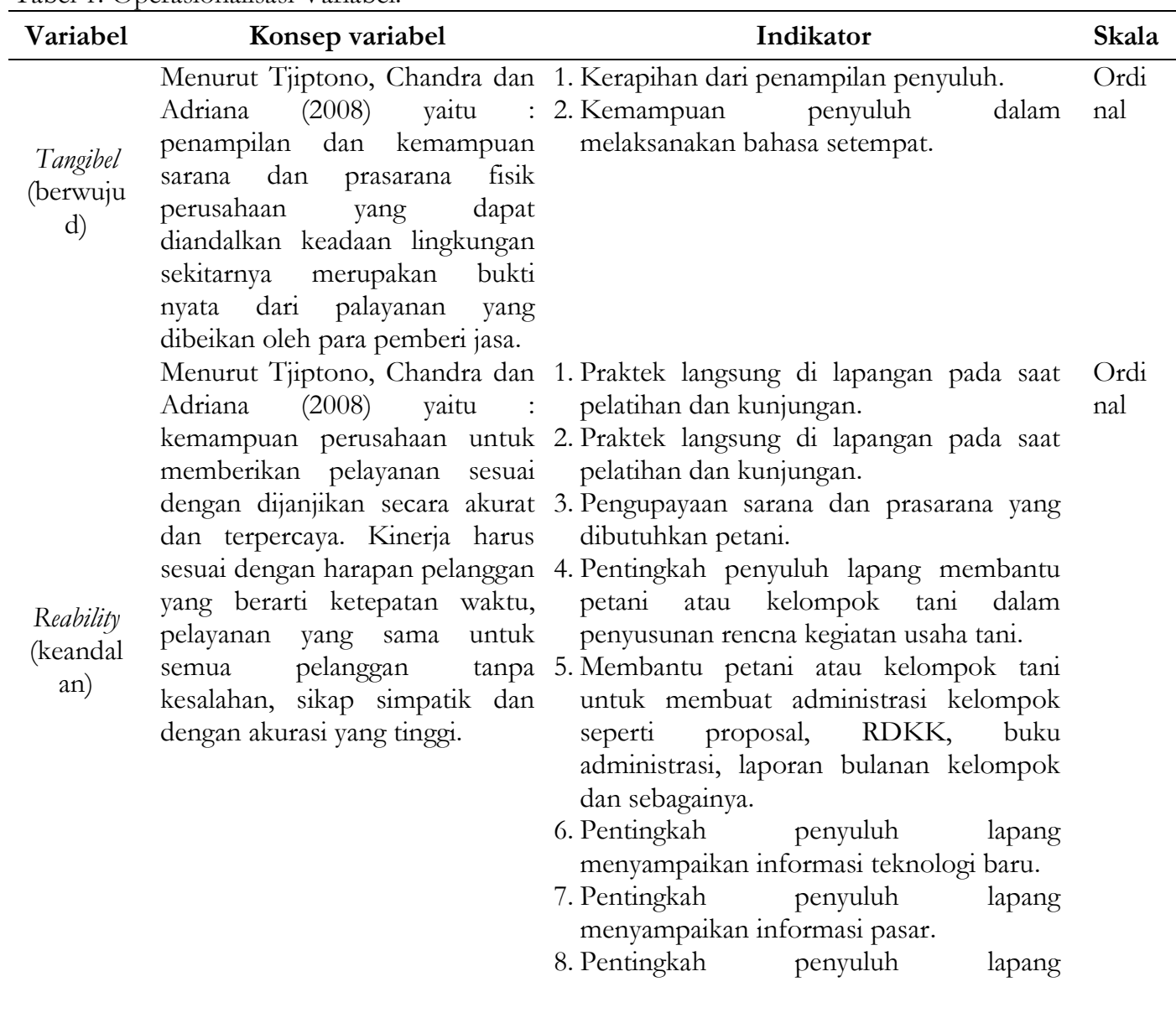


Assurance (kepastia n)

Responsive ness

(kesigapa

n)

Menurut Tjiptono, Chandra dan Adriana (2008) yaitu : suatu kebijakan untuk membantu dan memberikan pelayanan yang cepat dan tepat kepada pelanggan dengan penyampaian informasi yang jelas.

Menurut Tjiptono, Chandra dan Adriana (2008) yaitu : pengetahuan, kesopansantunan dan kemampuan para pegawai untuk mrnumbuhkan rasa percaya terhadap para pelanggan

Emphaty
(empati)

Kepuasa

$\mathrm{n}$

Konsum

en

Menurut Tjiptono, Chandra dan Adriana (2008) yaitu : memberikan perhatian yang tulus dan bersifat individual atau pribadi yang diberikan kepada para pelanggan dengan berupaya memahami keinginan konsumen. Menurut Tjiptono (2012) yaitu : kepuasan konsumen merupakan situasi yang ditunjukan oleh konsumen ketika mereka menyadari bahwa kebutuhan dan keinginannya sesuai dengan yang diharapkan serta terpenuhi secara baik. menyampaikan informasi peluang usaha dan permodalan.

9. Pengaruh penyuluh lapang terhadap peningkatan hasil usaha.

1. Kemampuan penyuluh untuk cepat tanggap dalam menghadapi masalah yang timbul.

2. Kecepatan dalam menangani pengaduan petani.

1. Memberikan bimbingan dan memecahkan masalah petani atau kelompok tani dalam pengambilan keputusan guna menjalin kemitraan usaha dibidang pertanian.

2. Pentingkah penyuluh berikap ramah.

3. Pengetahuan dan kecakapan dalam memberikan informasi yang jelas dan mudah dimenegrti kepada petani.

4. Memberikan pelayanan atau menyelesaikan masalah secara tuntas.

5. Pengetahuan dan kemampuan penyuluh dalam mengetahui permasalahan di lapangan (penyakit, hama, dll).

1. Mudah ditemui dan dihubungi untuk berkonsultasi.

2. Pelayanan yang sama kepada semua petani tanpa pilih-pilih.

3. Memberikan perhatian khusus (individual) atas masalah tertentu (khusus).

Ordi nal

Ordi nal

Ordi nal
Populasi dalam penelitian ini adalah seluruh petani yang ada di desa Sukasari Kecamatan Cilaku yang telah merasakan kinerja dari penyuluh lapangan di desa Sukasari.

Penentuan responden dalam penelitian ini berdasarkan metode purposive dan random sampling, dimana penentuan responden penelitian ini didasarkan pada metode Gay yang menyatakan bahwa jumlah sampel yang dinilai cukup mewakili keseluruhan populasi yaitu minimal $10 \%$ dari total populasi, jumlah keseluruhan dari kelompok tani Desa Sukasari yang berjumlah 448 orang dari 9 kelompok tani sehingga jumlah sampel yang diambil sebanyak 44 orang atau dibulatkan menjadi 45 orang untuk memberikan lebih besar peluang untuk menghasilkan distribusi normal.

Metode Importance Performance Analysis (IPA) merupakan suatu teknik pengembangan program pemasaran efektif yang bagaimana penerapannya sangat mudah untuk mengatur atribut dari tingkat kepentingan hingga tingkat pelaksanaan itu sendiri (Ruhimat, 2008). Dalam analisis Importance and Performance Analysis (IPA) ini terdapat 21 atribut yang 
hendak diujikan sehingga pengukuran tersebut menggunakan skala semantic differentials lima tingkat yang terdiri dari sangat penting, cukup penting, tidak penting dan sangat tidak penting. Penilaian setiap atribut yang akan menjadi bahan pertanyaan adalah sebagai berikut:

1) Jawaban sangat penting diberi nilai 5 .

2) Jawaban penting diberi nilai 4.

3) Jawaban cukup penting diberi nilai 3 .

4) Jawaban tidak penting diberi nilai 2 .

5) Jawaban sangat tidak penting diberi nilai 1.

Untuk rentang skala pada tingkat kepentingan adalah sebagai berikut:
1) $1.00-1.79$ berarti sangat tidak penting.

2) $1.80-2.59$ berarti tidak penting.

3) $2.60-3.39$ berarti cukup penting.

4) $3.40-4.19$ berarti penting.

5) $4.20-5.00$ berarti sangat penting.

Untuk rentang skala pada tingkat kinerja adalah sebagai berikut:

1) -1.79 berarti sangat tidak baik.

2) $1.80-2.59$ berarti tidak baik.

3) $2.60-3.39$ berarti cukup baik.

4) $3.40-4.19$ berarti baik.

5) $4.20-5.00$ berarti sangat baik.

Selanjutnya adapun gambar diagram kartesius IPA pada gambar :

\begin{tabular}{|c|c|}
\hline $\begin{array}{c}\text { Tingkat Kinerja } \\
1\end{array}$ & $\begin{array}{c}\text { Pertahankan Kinerja } \\
2\end{array}$ \\
\hline $\begin{array}{c}\text { Prioritas Rendah } \\
3\end{array}$ & $\begin{array}{c}\text { Cenderung Berlebihan } \\
4\end{array}$ \\
\hline $\begin{array}{l}\text { Customer satisfation Index atau } \\
\text { kepuasan konsumen merupakan sebuah } \\
\text { metode yang menggunakan indeks untuk }\end{array}$ & $\begin{array}{l}\quad \text { Keterangan: } \\
\mathrm{P}=\text { jumlah atribut kepentingan } \\
\mathrm{I}=\text { atribut ke } \mathrm{i}\end{array}$ \\
\hline
\end{tabular}

mengukur tingkat kepuasan konsumen secara menyeluruh terhadap kinerja penyuluh menurut Stratford (2008), pengukuran indeks ini dilakukan dengan 4 tahapan yaitu :

1. Menemukan Means Important Score (MIS) dan Means Satisfaction Score (MSS), berguna untuk mendapatkan nilai yang diperoleh berdasarkan nilai rata - rata tingkat kepentingan dan nilai rata - rata kinerja tiap responden.

Keterangan:

$\mathrm{N}=$ Jumlah responden

$\mathrm{Yi}=$ Nilai kepentingan atribut ke $\mathrm{i}$

$\mathrm{Xi}=$ Nilai konerja atribut ke $\mathrm{i}$

2. Membuat Weight Factor (WF), merupakan bobot ini persentase nilai MIS tiap atribut terhadap nilai MIS seluruh atribut. Rumusnya adalah sebagai berikut:

Wfi = MISi

3. Membuat Weight Score (WS), merupakan bobot ini untuk mendapatkan skor perkalian antara Weight Factor (WF) dan Means Satisfaction Score (MSS) atau rata-rata tingkat kepuasan, rumusannya adalah sebagai berikut:

$\mathrm{WS}=\mathrm{WFi} . \mathrm{MSS} i$

Total Weight Score (WS) atribut ke-1 (a1) hingga atribut terakhir (a-p) disebut dengan Weight Average Total (WAT).

4. Menentukan nilai CSI

$$
\begin{aligned}
& C S I=\frac{\sum_{i=1}^{p} W S i}{H S} \times 100 \% \\
& \text { Keterangan: } \\
& \mathrm{P}=\text { nilai ke } \mathrm{p} \\
& \text { HS = Skala maksimum yang } \\
& \text { digunakan. }
\end{aligned}
$$


Tabel 2. Kriteria Nilai Customer Satisfaction Index

\begin{tabular}{|c|c|}
\hline Nilai CSI & Kriteria CSI \\
\hline $0 \%<\mathrm{CSI} \leq 20 \%$ & Sangat tidak puas \\
\hline $20 \%<\mathrm{CSI} \leq 40 \%$ & Tidak puas \\
\hline $40 \%<\mathrm{CSI} \leq 60 \%$ & Cukup puas \\
\hline $60 \%<\mathrm{CSI} \leq 80 \%$ & Puas \\
\hline $80 \%<\mathrm{CSI} \leq 100 \%$ & Sangat puas \\
\hline
\end{tabular}

\section{HASIL DAN PEMBAHASAN}

Desa Sukasari mempunyai luas lahan 526,45 ha yang terdiri dari lahan sawah seluas 254,47 ha dan lahan darat seluas 271,98 ha. Secara administratif Desa Sukasari Kecamatan Cilaku kabupaten Cianjur berbatasan dengan :

1. Sebelah Utara berbatsan dengan Desa Sukakerta dan Desa Sirnagalih.

2. Sebelah Timur berbatasab dengan Desa Sukakerta.

3. Sebelah Selatan berbatasan dengan

Desa Peteuy Condong.

4. Sebelah Barat berbatasan dengan Desa Sukamulya

Desa Sukasari berdasarkan topografinya merupakan daerah datar dengan ketinggian tempat $450 \mathrm{~m}$ dpl dan jenis tanah yang dominan asosiasi alluvial kelabu dan asosiasi kekelabuan, rata - rata curah hujan selama lima tahun berkisar pada $1000-1500 \mathrm{~mm} /$ tahun dengan 80 hari hujan/pertahun.

Penyebaran kuisioner pada penelitian ini dilakukan terhadap 45 orang petani di Wilayah Kerja BPP Cilaku di Desa Sukasari dengan berbagai karakteristik yang telah ditetapkan. Adapun karakteristik yang telah ditetapkan adalah (1) Jenis Kelamin, (2) Usia, (3) Pendidikan, (4) Pengalaman bertani.

Pada gambar dibawah ini dapat dilihat jumlah responden, responden berdasarkan jenis kelamin di Desa Sukasari adalah berjenis kelamin laki - laki sejumlah 45 orang. Hal ini disebabkan sebagian besar petani di wilayah kerja BPP Cilaku berjenis kelamin laki - laki yang menjadi tulang punggung keluarga.

\section{Jenis Kelamin}

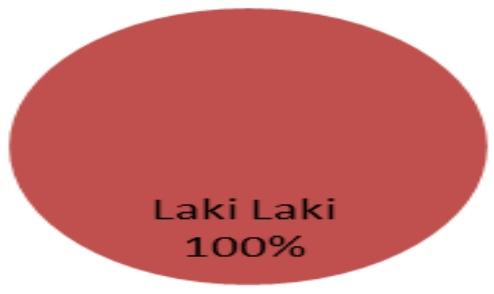

Gambar 1. Responden berdasarkan jenis kelamin

Berdasarkan penyebaran usia responden, rata - rata usia responden yaitu usia antara $<50->50$ tahun. Usia responden yang paling banyak yaitu usia yang lebih dari 50 tahun sebanyak $73 \%$
(33 orang) dan yang terkecil usia dibawah 50 tahun sebanyak $27 \%$ (12 orang). Dalam usia lebih dari 50 tahun dapat dikatakan sebagai orang dewasa yang sudah banyak memiliki pengalaman. 


\section{Usia Responden}

- $<50$ tahun $\quad$ >50 tahun

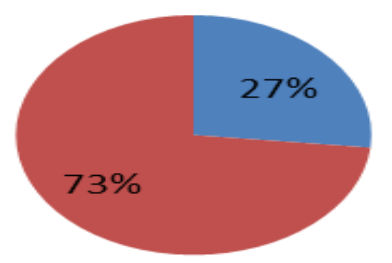

Gambar 2. Responden berdasarkan Usia.

Karakteristik responden berdasarkan pendididikan. Jumlah responden terbesar adalah responden dengan pendiddikan SD yaitu sebesar $51 \%$ (23 orang), responden dengan pendidikan SMP sebanyak 40\% (18 orang), responden dengan pendidikan SMA sebanyak $7 \%$ (3 orang), dan responden dengan pendidikan Perguruan Tinggi sebanyak 2\% (1 orang).

Hal ini dikarenakan pedidikan dan pekerjaan adalah dua hal yang saling berhubungan, sebagian besar orang memilih jenis pekerjaan yang sesuai dengan pendiddikannya.

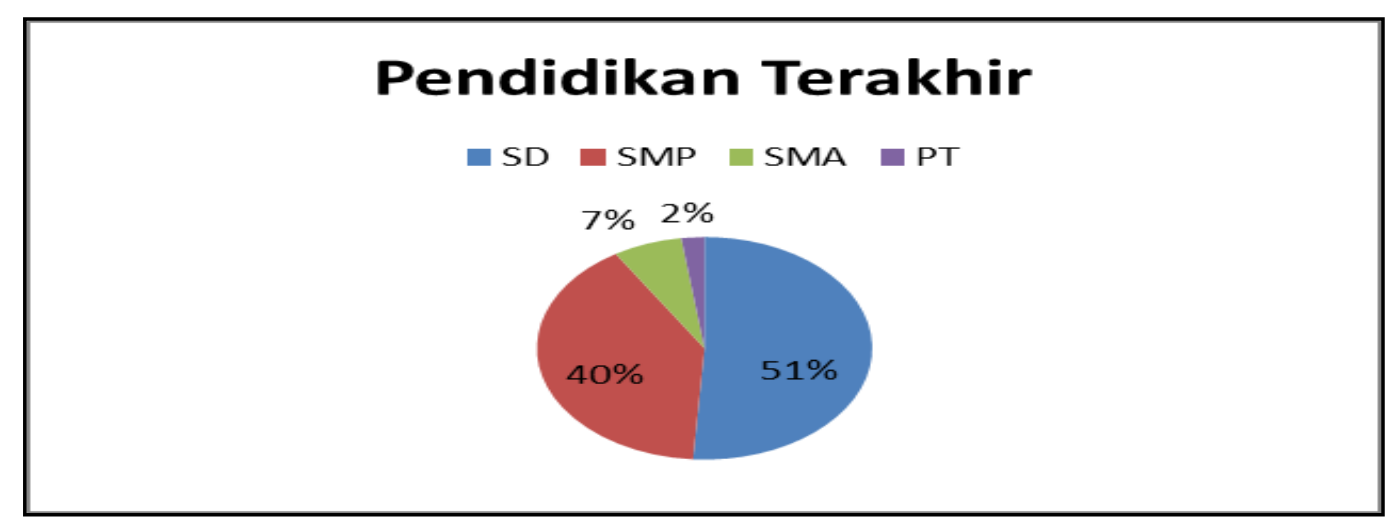

Gambar 3. Responden berdasarkan Pendidikan Terakhir.

Gambar dibawah merupakan karakteristik responden berdasarkan pengalaman, dimana petani tersebut cukup mempunyai pengalaman yang cukup lama. Pengalaman petani 1 - 5 tahun sebanyak $2 \% \quad$ ( 1 orang), pengalaman 6 - 10 tahun sebanyak 98\% ( 44 orang). 


\section{Pengalaman Petani}

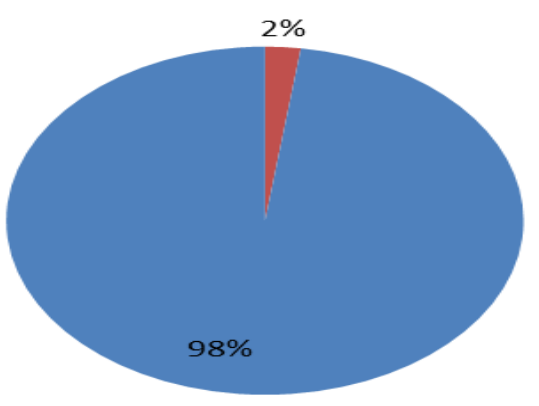

- 1-5 tahun

- 6-10 tahun

Gambar 4. Berdasarkan Pengalaman Petani.

Mutu pelayanan yang diberikan penyuluh lapangan BPP Cilaku akan sangat berpengaruh penilainnya yang diberikan oleh petani yang mendapatkan pelayanan dari penyuluh lapangan di BPP Cilaku. Harapan petani mengenai pelayanan penyuluh lapangan di BPP Cilaku, diharapkan diimbangi dengan kinerja yang dilakukan oleh penyuluh lapangan BPP Cilaku.

Adapun atribut - atribut yang digunakan untuk menilai tingkat kepentingan dan kinerja terhadap penyuluh lapangan di BPP Cilaku bisa dilihat pada tabel 3 sebagai berikut :

Tabel 3, Atribut - atribut Penilaian tingkat kepentingan dan kinerja terhadap penyuluh lapangan di BPP Cilaku.

\begin{tabular}{llc}
\hline \multirow{2}{*}{ Dimensi } & \multicolumn{1}{c}{ Atribut - Atribut Pelayanan } & \\
\hline Tangible & 1. Kerapihan dan penampilan penyuluh & A1 \\
& 2. Kemampuan penyuluh dalam melaksanakan bahasa setempat & A2 \\
\hline \multirow{5}{*}{ 1. Praktek langsung di lapangan } & A3 \\
& 2. Pelatihan dan kunjungan secara teratur oleh penyuluh & A4 \\
& 3. Pengupayanan sarana dan prasarana & A5 \\
& 4. Penyusunan rencana kegiatan usaha tani & A6 \\
& 5. Membantu administrasi kelompok & A7 \\
& 6. Memberikan informasi teknologi baru & A8 \\
& 7. Memberikan informasi pasar & A9 \\
& 8. Memberikan informasi peluang usaha dan permodalan & A10 \\
& 9. Peningkatan hasil usaha & A11 \\
\hline \multirow{2}{*}{ Responsiveness } & 1. Cepat tanggap dalam menghadapi masalah yang timbul & A12 \\
& 2. Kecepatan menangani pengaduan petani & A13 \\
\hline \multirow{5}{*}{ Assurance } & 1. Membantu dalam pengambilan keputusan guna menjalin kemitraan & \multirow{2}{*}{ A14 } \\
& 2. Keramahan & A15 \\
& 3. Pengetahuan dan kecakapan dalam memberikan materi & A16 \\
& 4. Pelayanan / menyelesaikan masalah secara tuntas & A17 \\
& 5. Pengetahuan permasalahan di lapangan & A18 \\
\hline \multirow{2}{*}{ Emphathy } & 1. Mudah ditemui atau dihubungi & A19 \\
& 2. Pelayanan yang sama kepada petani & A20 \\
3. Perhatian khusus atau masalah tertentu & A21 \\
\hline
\end{tabular}

Adapun penjabaran untuk masing

- masing atribut adalah sebagai berikut :

1. Dimensi Tangible (berwujud)

a. Kerapihan dan penampilan penyuluh
Kerapihan dan penampilan penyuluh merupakan atirbut yang dapat dilihat langsung oleh petani dan termasuk 
salah satu atribut yang sering dinilai langsung oleh petani.

\section{Dimensi Reliability (keandalan)}

a. Praktek langsung dilapangan

Praktek langsung di lapangan merupakan hal yang penting untuk mempraktekan langsung materi yang disuluhkan seperti teknis cara penanaman, pemupukan, pemberia pakan untuk ternak serta bagaimana penangan hasil usaha pertanian.

b. Pelatihan dan kunjungan secara teratur oleh petani

Pertemuan yang rutin antara penyuluh dengan petani dilakukan untuk mendiskusikan permasalahan yang timbul dan melihat perkembangan petani.

c. Pengupayaan sarana dan prasarana

Pengupayaan sarana dan prasarana ini sangat diinginkan oleh petani untuk kegiatan usaha baik dalam bentuk bantuan langsung, seperti pengadaan traktor, obat obatan, bibit, dan lain-lain.

d. Penyusunan rencana kegiatan usaha tani

Rencana kegiatan usaha tani sangat diperlukan oleh petani untuk mengetahui perkiraan biaya dan hasil usaha yang akan didapat.

e. Membantu administrasi kelompok Kelompok tani diwajibkan membuat kelengkapan administrasi kelompoknya seperti Rencana Defentif Kebutuhan Kelompok (RDKK), Rencana Usaha Kelompok (RUK), berita acara pembentukan dan sebagainnya.

f. Memberikan informasi teknologi batu Memberikan informasi yang luas kepada para petani mengai teknologi baru yang penting dilakukan guna meningkatkan hasil taninya. Teknologi tersebut dapat berupa informasi benih unggul, cara penanaman, pemupukan, pemberian pakan serta pengolahan hasil pertanian. g. Memberikan informasi pasar

Memebrikan informasi yang luas kepada petani dalam hal informasi pasar dapat membantu petani untuk mempermudah penjualan hasil usahannya. Sebagai penyuluh tetntunya harus dapat memebantu petani mencari pasar yang dapat menguntungkan petani.

h. Memberikan informasi peluang usaha dan permodalan

Memberikan informasi yang luas kepada petani dalam hal pengadaan permodalan dan peluang usaha yang dapat memperlancar peningkatan usaha tani, misalnya informasi kredit usaha tani, kredit sarana kebutuhan petani, dan menampung hasil usaha para petani yang akan memuaskan para petani.

i. Peningkatan hasil usaha

Dengan adanya penyuluhan diharapkan dapat meningkatkan hasil usaha para petani yang akan berdampak pada peningkatan keuntungan serta meningkatkan taraf hidup petani.

3. Dimensi Responsiveness (kesigapan)

a. Cepat tanggap dalam menghadapi masalah yang timbul

Kemampuan penyuluh untuk cepat tanggap dalam mengahdapi masalah yang timbul baik mengenai teknis di lapangan seperti hama atau penyakit maupun masalah yang timbul di kelompok. Penyuluh harus segera dapat mengatasi masalah tersebut agar tidak mempengaruhi hasil usaha aktivitas petani. b. Kecepatan menangani pengaduan
petani

Dalam atribut ini diperlukan suatu kemampuan untuk cepat tanggap dan penyuluh terhadap keluhan atau pengaduan yang disampaikan oleh petani. 


\section{Dimensi Assurance (kepastian)}

a. Membantu pengambilan keputusan guna menjalin kemitraan usaha

Penyuluh harus dapat membantu petani dalam masalah pengambilan keputusan tersebut, karena hal ini akan menentukan keberhasilan usaha petani.

b. Keramahan penyuluh

Dalam memberikan penyuluhan yang efektif, diharapkan penyuluh bersikap ramah serta siap menolong kepada petani.

c. Pengetahuan dan kecakapan dalam memberikan materi

Atribut ini menuntut penyuluh untuk memiliki pengetahuan mengenai materi yang akan disuluhkannya serta cara berkomunikasi yang baik agar materi yang dibeikan mudah dimengerti oleh petani.

d. Pelayanan dan menyelesaikan masalah secara tuntas

Pelayanan secara tuntas akan membuat petani lebih mengandalkan dan yakin akan keberadaan penyuluh lapangan.

e. Pengetahuan permasalahan di lapangan

Pengetahuan dan kemampuan penyuluh dalam mengatahui permasalahan di lapangan akan sangat membantu petani untuk menyelesaikan masalah mereka, mulai dari maslaah teknis di lapangan ataupun masalah administrasi kelompok tani.

\section{Dimensi Empathy (empati)}

a. Mudah ditemui atau dihubungi

Kemudahan untuk ditemui dan dihubungi untuk berkonsultasi, akan membuat petani merasa nyaman, merasa bahwa penyuluh benra - benar mempperhatikan petani dan benar benar ada untuk petani.

b. Pelayanan yang sama kepada petani

Pemberian pelayanan yang sama kepada semua petani dapat menimbulkan kenyamanan bagi petani, sehingga tidak terjadi perbedaan kelas sosial dalam seuatu kelompok tani.

c. Perhatian khusus atas masalah tertentu Adanya permasalahan tertentu yang dihadapi seorang petani, memerlukan penanganan khusus secra perorang secara langsung kepada individu yang bersangkutan, dengan begitu masalah yang timbul akan mudah diatasi.

Analisis IPA digunakan untuk mengukur tingkat kepusan konsumen secara menyeluruh terhadap kinerja atribut - atribut penyuluh. Hasil dari pengujian analisis IPA dapat dilihat pada gambar 5:

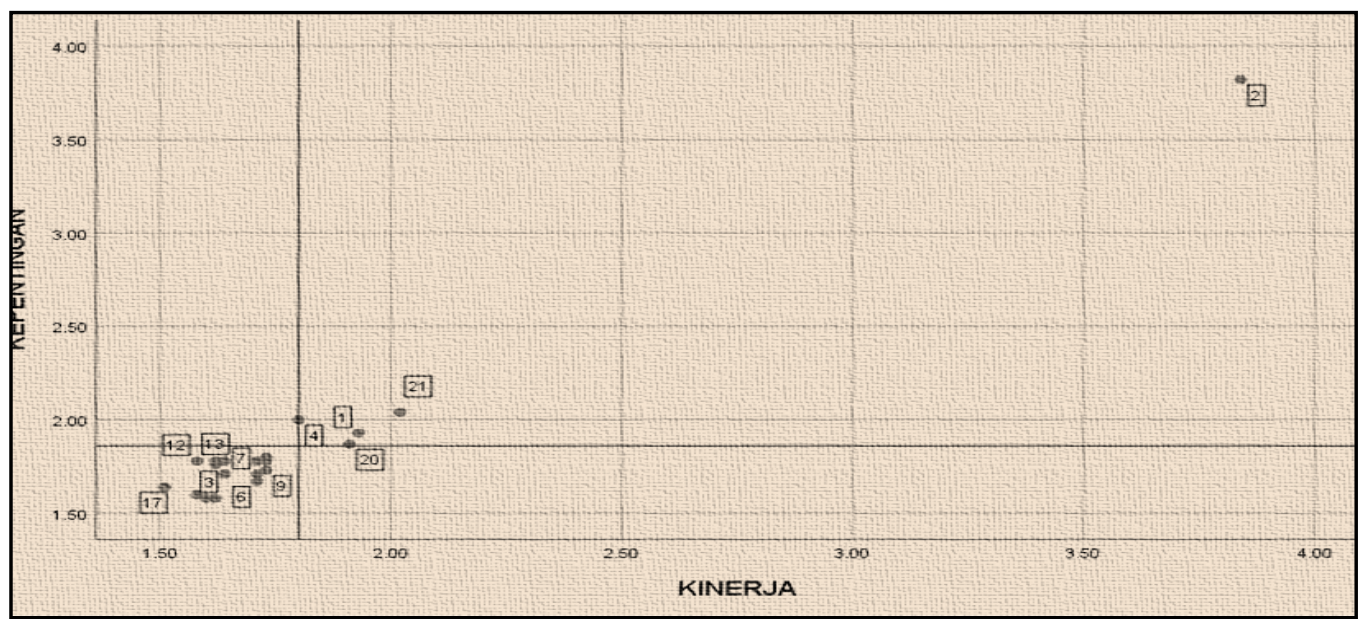

Gambar 5. Diagram Kartesius IPA Peran Penyuluh. 
Dari gambar 5. dapat dilihat beberapa lingkaran kecil yang memiliki posisi tersebar, hal itu menandakan atribut - atribut penyuluh dari atribut 1 - 21 yang terbagi dalam 4 (plot) atau bagian - bagian tersebut disebut kuadran dan memiliki arti dan perlakuan yang harus dilakukan berbeda antar kuadran.

\section{A. Kuadran 1 Prioritas Utama}

Atribut - atribut yang berbeda pada kuadran ini dianggap sangat penting oleh petani tetapi pelayanan kurang memuaskan. Beberapa atribut seperti yang ada pada kuadran 1.

Disini petani merasakan atribut pelayanan yang ada dianggap penting tetapi pada kenyataannya atribut -atribut tersebut belum sesuai dengan kepuasannya, sehingga penyuluh pertanian harus mengupayakan sumberdaya yang memadai untuk meningkatkan kinerja pada berbagai atribut tersebut.

Atribut yang terletak pada kuadran ini merupakan prioritas untuk ditingkatkan agar kepuasan petani dapat ditingkatkan.

\section{B. Kuadran 2 Pertahankan Kinerja}

Pada kuadran 2 pertahankan kinerja dimana atribut - atribut kinerja penyuluh seperti :

No 1. Kerapihan dari penampilan penyuluh.

No 2. Kemampuan penyuluh dalam melaksanakan bahasa setempat.

No 4. Pelatihan dan kunjungan secara teratur oleh penyuluh.

No 20. Pelayanan yang sama kepada petani tanpa pilih - pilih.

No 21. Memberikan perhatian khusus atas masalah tertentu.

Atribut - atribut yang terletak pada kuadran ini dianggap sebagai faktor penunjang bagi kepuasan petani. Artinya, jika penyuluh dapat mempertahankan kinerja pada hal - hal yang dianggap penting terhadap pelayanan penyuluh. Sehingga penyuluh berkewajiban mempertahankan prestasi yang telah dicapai.

\section{Kuadran 3 Prioritas Rendah}

Di kuadran ini petani tidak mengangap penting dan belum merasakan kepuasannya terhadap atribut pelayanan yang diberikan oleh penyuluh lapangan sehingga penyuluh tidak perlu memprioritaskan atau terlalu memberikan perhatian pada atribut tersebut, cukup sekedar mempertahankan dan menyesuaikan dengan kondisi saat ini. Atribut tersebut yaitu :

No 3. Praktek langsung di lapangan.

No 5. Pengupayanan sarana dan prasarana yang dibutuhkan petani.

No 6. Pentingnya penyuluh lapang membantu petani atau kelompok tani dalam penyusunan rencana kegiatan usaha tani.

No 7. Membantu petani atau kelompok tani untuk membuat administrasi kelompok seperti proposal, RDKK, buku administrasi, laporan bulanan kelompok dan sebagainnya.

No 8. Penyuluh lapang menyampaikan informasi teknologi baru.

No 9. Penyuluh lapang menyampaikan informasi pasar.

No 10. Memberikan informasi peluang usaha dan permodalan.

No 11. Pengaruh penyuluh lapangan terhadap peningkatan hasil usaha.

No 12. Cepat tanggap dalam menghadapi masalah yang timbul.

No 13. Kecepatan dalam menangani pengaduan petani.

No 14. Memberikan bimbingan dan memecahkan masalah petani atau kelompok tani dalam pengambilan keputusan guna menjalin kemitraan usaha dibidang pertanian.

No 15. Pentingnya penyuluh bersikap ramah.

No 16. Pengetahuan dan kecakapan dalam memberikan infomasi yang jelas dan mudah dimengerti kepada petani.

No 17. Memberikan pelayanan atau menyelesaikan masalah secara tuntas. 
No 18. Pengetahuan dan kemampuan penyuluh dalam mengetahui permasalahan di lapangan (penyakit, hama, dll).

No 19. Mudah ditemui dan dihubungi untuk berkonsultasi.

No 20. Pelayanan yang sama kepada semua petani tanpa pilih - pilih.

\section{Kuadran 4 Cenderung Berlebihan}

Di sini petani merasakan atribut yang ada dianggap sudah memuaskan, namun tidak terlalu penting oleh petani sehingga penyuluh tidak perlu terlalu banyak mengalokasikan sumberdaya yang terkait dengan atribut - atribut tersebut, cukup hanya sekedar mempertahannya.

Dari data yang telah diperoleh melalui kuesioner yang telah diberikan dan dijawab oleh setiap petani maka tahap selanjutnya dilakukan analisis CSI. Metode CSI digunakan untuk menganalisis sejauh mana tingkat kepentingan dan tingkat kinerja atribut penyuluh hasilnya dapat dilihat pada tabel 4. sebagai berikut:

Tabel 4. Perhitungan Custumer Satisfation Index (CSI).

\begin{tabular}{|c|c|c|c|c|c|}
\hline No & Atribut - Atribut Pelayanan & MIS & MSS & WF & WS \\
\hline A1 & $\overline{\text { Kerapihan dan penampilan penyuluh }}$ & 1,93 & 1,93 & 0,054 & 0,105 \\
\hline A2 & $\begin{array}{l}\text { Kemampuan penyuluh dalam melaksanakan bahasa } \\
\text { setempat }\end{array}$ & 3,82 & 3,84 & 0,097 & 0,375 \\
\hline A3 & Praktek langsung di lapangan & 1,71 & 1,64 & 0,048 & 0,079 \\
\hline A4 & Pelatihan dan kunjungan secara teratur oleh penyuluh & 2,00 & 1,80 & 0,056 & 0,102 \\
\hline A5 & Pengupayanan sarana dan prasarana & 1,60 & 1,58 & 0,045 & 0,071 \\
\hline A6 & Penyusunan rencana kegiatan usaha tani & 1,67 & 1,71 & 0,047 & 0,081 \\
\hline A7 & Membantu administrasi kelompok & 1,71 & 1,71 & 0,048 & 0,083 \\
\hline A8 & Memberikan informasi teknologi baru & 1,69 & 1,60 & 0,047 & 0,076 \\
\hline A9 & Memberikan informasi pasar & 1,73 & 1,73 & 0,049 & 0,085 \\
\hline A10 & Memberikan informasi peluang usaha dan permodalan & 1,58 & 1,60 & 0,044 & 0,071 \\
\hline A11 & Peningkatan hasil usaha & 1,78 & 1,73 & 0,050 & 0,087 \\
\hline A12 & Cepat tanggap dalam menghadapi masalah yang timbul & 1,78 & 1,58 & 0,050 & 0,079 \\
\hline A13 & Kecepatan menangani pengaduan petani & 1,78 & 1,62 & 0,050 & 0,081 \\
\hline A14 & $\begin{array}{l}\text { Membantu dalam pengambilan keputusan guna menjalin } \\
\text { kemitraan usaha }\end{array}$ & 1,80 & 1,73 & 0,051 & 0,088 \\
\hline A15 & Pentingnya penyuluh ramah & 1,76 & 1,62 & 0,049 & 0,080 \\
\hline A16 & Pengetahuan dan kecakapan dalam memberikan materi & 1,78 & 1,64 & 0,050 & 0,082 \\
\hline A17 & Pelayanan / menyelesaikan masalah secara tuntas & 1,64 & 1,51 & 0,046 & 0,070 \\
\hline A18 & Pengetahuan permasalahan di lapangan & 1,58 & 1,62 & 0,044 & 0,072 \\
\hline A19 & Mudah ditemui atau dihubungi & 1,78 & 1,71 & 0,050 & 0,086 \\
\hline A20 & Pelayanan yang sama kepada petani & 1,87 & 1,91 & 0,053 & 0,101 \\
\hline \multirow[t]{5}{*}{ A21 } & Perhatian khusus atau masalah tertentu & 2,04 & 2,02 & 0,057 & 0,117 \\
\hline & Total & 39,03 & 37,83 & 1 & 1,915 \\
\hline & Weight Average Total (WAT) & 1,916 & & & \\
\hline & Custumer Satisfaction Index (CSI) & 38,31 & & & \\
\hline & & $\%$ & & & \\
\hline
\end{tabular}

Sumber: Data Primer (diolah), 2019

Tabel di atas menunjukan bahwa nilai indeks kepuasan petani sebesar 38,31\%. Nilai tersebut berada pada rentang antara $20 \%<$ CSI $\leq 40 \%$ berada pada kategori kurang puas atas atribut - atribut.

\section{KESIMPULAN}

Kesimpulan dari hasil penelitian yang telah disusun dapat dipaparkan dalam pembahasan, terdapat beberapa kesimpulan sebagai berikut :

1. Pelayanan penyuluh atas peran tersebut memiliki tingkat kepentingan dengan hasil penilaian keseluruhan dari petani. Dapat disimpulkan dari data penilaian di atas tingkat kepentingan maupun tingkat kinerja yang telah diketahui hasilnya, dengan nilai rata rata tingkat kepentingan sebesar 1,86 dan tingkat kinerja dengan nilai rata rata 1,80. Hal ini menunjukan tingkat 
kepuasan petani yang kurang merasa puas atas kinerja yang diberikan oleh penyuluh lapangan di Desa Sukasari Kecamatan Cilaku Kabupaten Cianjur atas harapan dan kepentingan yang dibutuhkan oleh setiap petani. Tetapi tidak semua atribut tidak penting dan tidak puas yang di anggap oleh petani, ada beberapa atribut yang menjadi harapan - harapan petani yang bisa di pertahankan atau ditingkatkan oleh penyuluh lapangan di Desa Sukasari Kecamatan Cilaku Kabupaten Cianjur. Atribut tersebut adalah (No 1.) Kerapihan dari penampilan penyuluh (No 2.) Kemampuan penyuluh dalam melaksanakan bahasa setempat (No 4.) Pelatihan dan kunjungan secara teratur oleh penyuluh (No 20.) Pelayanan yang sama kepada petani tanpa pilih - pilih (No 21.) Memberikan perhatian khusus atas masalah tertentu.

2. Hasil pengolahan data yang telah diperoleh maka dapat disimpulkan bahwa Costumer Satification Index (CSI) 38,31\% Nilai tersebut ada pada rentang antara $20 \%<$ CSI $\leq 40 \%$. Menunjukan petani merasa kurang puas atas atribut atau peran yang dilakukan oleh penyuluh lapangan.

\section{DAFTAR PUSTAKA}

. 2005. Metode Pene;itian Untuk Skripsi dan Tesis Bisnis . Jakarta. Raja Grafindo Persada.

2015. Statistika Untuk Penelitian. Alpabeta. Bandung.

Arikunto. 2002. Prosedur Penelitian Suatu Pendekatan Praktek. Jakarta: Rineka Cipta.

Chandra, Adriana. 2008. Pemasaran Strategik. Ansi. Yogyakarta.

Erni, Maryana. 2001. Kinerja Petugas Lapangan. Lembaga Pendidikan Managemen. Jakarta.

Kalalinggi, Rita. Paranoan, DB dan Wijayanti Naning. Analisis Tingkat Kepuasan Petani Terhadap Kinerja
Penyuluh Pertanian Lapangan (PPL) di

Kabupaten Kutai Timur.

Kotler, Amstrong. 2004. Dasar-Dasar Pemasaran. Edisi kesembilan, Jakarta:Gramedia.

Listiani, Ika. 2010. Analisis Tingkat kepuasan Petani Terhadap Kinerja Penyuluh Lapang di BP3K Wilayah Ciawi Kabupaten Bogor. Fakultas Ekonomi dan Manajemen Institut Pertanian Bogor.

Mardikanto, 2009. Sistem Penyuluhan Pertanian. Sebelas Maret University press. Surakarta.

Nuraeni. 2007. Kemampuan berbahasa Inodnesia. Bandung: PT. Remaja Rosdakarya.

Nuryana, Ayi Khobul. 2018. Tingkat Kepuasan Stakeholder Padi Pandanwangi Cianjur

Terhadap Keberadaan dan Peran Masyarakat Pelestari Padi Pandanwangi Cianjur (MP3C). Skrispsi. Fakultas Sains Terapan Universitas Suryakancana Cianjur.

Peraturan Menteri Pertanian Nomor 82/Permentan/OT. 140/8/2013. Pedoman Pembinaan Kelompok tani dan Gabungan Kelompok tani. Jakarta.

Priyono, 2009. Tujuan Penyuluhan Pertanian. Ilmu Ternak. Universitas Diponegoro. Semarang.

Rangkuti, F. 2006. Measuring Costumer Satisfaction. Gramedia Pustaka Umum.Jakarta.

Ruhimat. 2011. Kurikulum DAN Pembelajaran. Jakarta. PT Raja Grafindo Persada.

Subagyo, 2010. Marketing In Business. Edisi pertama, cetakan pertama. Jakarta: Mitra Wacana Media.

Subagyo, Dini Bayu. 2010. Tingkat Kepuasan Petani Terhadap Kinerja Pelayanan Penyuluh Pertanian di Desa Situ Udik Kecamatan Cibungbulang kabupaten Bogor Jawa Barat. Fakultas 
Ekonomi dan Manajemen Institut Pertanian Bogor.

Sugiyono. 2011. Metode Penelitian Bisnis. Bandung : CV. Alfabeta.

Supranto. 2001. Pengukuran Tingkat

Kepuasan Pelanggan untuk Menaikan pangsa pasar. Rineka Cipta. Jakarta.

Suwandi, A. 2006. Administrasi Penyulub Pertanian. Jakarta. Universitas Terbuka.

Tjptono, Fandy. 2004. Manajemen Pemasaran jasa. Yogyakarta. Andi Offiset.

Umar, H. 2003. Riset Sumberdaya Manusia dalam Organisasi. Jakarta. Bumi Pemasaran Jasa. Salemba Empat. Jakarta.

Margono. 2000. Metode penelitian pendidikan Jakarta: Rineka Cipta.

Marius P. Angiopora. 2002. Dasar-Dasar Pemasaran . Edisi Kedua.PT Raja Grafindo Persada. Jakarta.

Sekaran. 2003. Research Method For Business: A Skill Building Approach.
Siti Fatonah dan Sigit R. Soebandiono. 2010. Analisis Faktor-faktor Marketing Mix Yang Mempengaruhi Keputusan Konsumen Membeli Benih Jagung Hibrida Pioneer P21 Di Kabupaten Bantul. STIE "AUB". Surakarta.

Sugiyono. 2011. Metode Penelitian Bisnis . Bandung: CV, Alfabeta.

Sugiyono. 2015. Statistika Untuk Penelitian. Alpabeta. Bandung.

Suharsimi Arikunto. 2002. Metodologi Penelitian. Rineka Cipta. Jakarta.

Tarigan, H. G.2013. Berbicara sebagai suatu keterampilan berbahasa. Bandung: Angkasa.

Tjiptono, Fandy. 2006. Prinsip - Prinsip Total Quality Service (TQS). ANDI. Jakarta.

Tjptono, Fandy. 2001. Kualitas jasa: Pengukuran, Keterbatasan, dan Implikasi Manajerial. Majalah Manajemen Usahawan Indonesia . Jakarta. 